САМОРЕАЛИЗАЦИЯ ЛИЧНОСТИ В ОБЩЕСТВЕ

\section{SELF-REALIZATION OF THE INDIVIDUAL IN SOCIETY}

\section{O. Apanasenko \\ A. Kuryakov \\ I. Semenchenko}

Summary: The article deals with the problem of successful self-realization of a person, which is determined by a person's awareness of his own capabilities and potentials in various types of his activity. It is emphasized that it is extremely important to develop the ability to adapt their professional and personal goals to the trends of modern society. Selfrealization is an integral component of a full-fledged human life, without which it is not conceivable as a biosocial species.

Keywords: individuality, self-realization, the need of society, social values, creativity.

\author{
Апанасенко Ольга Николаевна \\ к.n.н., доцент, Бийский филиал Алтайского \\ государственного университета \\ oapanasenko@bk.ru \\ Куряков Алексей Владимирович \\ к.п.н., дочент, Бийский филиал Алтайского \\ государственного университета \\ Семенченко Ирина Витальевна \\ к.n.н., доцент, Бийский филиал Алтайского \\ государственного университета
}

Аннотация: В статье рассматривается проблема успешности самореализации личности, которая определяется осознанием человеком собственных возможностей и потенциалов в различных видах его активности. Подчеркивается, что крайне важно сформировать способность адаптировать свои профессиональные и личностные цели к тенденциям развития современного общества. Самореализация - неотъемлемый компонент полноценной жизни человека, без которой он не мыслим, как биосоциальный вид.

Ключевые слова: индивидуальность, самореализация, потребность общества, общественные ценности, творчество.

зации, реализации гуманистических идеалов. «Они же отмечают, - пишет Л.П. Буева, - падение ценностей одностороннего эгоцентризма и возрастание значения «социальности», человеческих форм общности и общения, духовного родства, человеколюбия и т.п.» [1, с.497].

В подобном аспекте высказывался известный социальный психолог Э. Фромм. Он писал, что «цель человека быть многим, а не обладать многим» [2, с. 44]. Становление человека высшей ценности означает принятие каждой индивидуальностью принципа оптимальной самореализации, развития и применения своих сил и способностей.

В самореализации индивид не противостоит внешнему миру, обществу, социальным институтам, а находится в активно преобразующем отношении к ним. Тем самым можно говорить о диалектическом взаимодействии уникальной, неповторимой личности и объективного мира в процессе самореализации. Процесс самореализации приводит к усложнению структуры личности, изменению ее уникального внутреннего мира, а это, в свою очередь, ведет к стремлению объективизации этой новой субъективности. Процесс самореализации неразрывно связан с деятельностью человека, его трудом, общением, творчеством. В самореализации человеческая индивидуальность предстает в единстве эмоциональных и интеллектуальных сторон, биологических задатков и приобретенных социальных качеств.

Многие мыслители прошлого исходили из необхо- 
димости создания таких общественных отношений, в которых человеческая природа могла бы полностью, т.е. свободно, реализоваться. Они обосновывали гуманистическую идею о том, что люди реализуют свои качества именно в свободе. Так, еще Б. Спиноза проводил связь между идеей самореализации и свободой, считая, что свобода существует по необходимости собственной природы и является действенной, ибо она не просто свобода действий, а проявляется как свобода необходимости. В рамках этой концепции свободным является тот человек, который реализовал свое внутреннее определение как необходимое в его природе.

Проблема самореализации человека, творчества и свободы стоит в центре анализа человеческой субъективности в диалектике Г.В.Ф. Гегеля. Диалектически понимая отношение человеческой субъективности к объекту и бытие субъекта как процесс его объективизации. Гегель заметил творческую, гуманистическую функцию труда и высказал в связи с этим интересные мысли, связанные с проблемой самореализации. Человек, считал Гегель, объективизируется в ходе практической деятельности и посредством ее достигает осознания самого себя, «ему присуще влечение порождать самого себя в том, что ему непосредственно дано... Этой цели он достигает посредством изменения внешних предметов, запечатлевая в них свою внутреннюю жизнь и снова находя в них свои собственные определения. Самореализация человека является, следовательно, «самопроизводством» его «во внешних вещах».

Философской основой взглядов 3. Фрейда на проблему самореализации человеческого индивида явился натуралистический антропологизм. Согласно Фрейду, глубинная сущность самореализации человека основывается на его доминирующих инстинктах, либидо, подсознательном уровне психики, которые он стремится реализовать, но этому препятствуют социальные нормы. Самореализация индивида, таким образом, выступала как его антиобщественная потребность.

В теории К. Маркса трактовка самореализации связана с идеей отчуждения труда, несвободной деятельности индивида. Маркс писал, что «в самом акте воспроизводства изменяются не только объективные условия, но изменяются и сами производители, вырабатывая в себе новые качества, развивая и преобразовывая самих себя благодаря производству, создавая новые силы и новые представления, новые способы общения, новые потребности и новый язык» [4, с. 483]. По Марксу к самореализации отдельного человека можно применить мысль о том, что он своей деятельностью участвует в создании своих потребностей, создании самого себя, формировании своей личности.

Оптимальная самореализация индивида возмож- на тогда, когда социальные задачи становятся его собственными задачами. Совпадение индивидуальных потребностей личности с общественными потребностями, ориентация личности на решение общественных задач не означает ограничение свободной самореализации личности, а, напротив, превращает ее в социально максимально содержательную, стимулирует деятельность и развитие личности в направлении развития всего общества.

Вырабатывая понимание потребностей общества, личность развивает способность познавать общественную необходимость, которая превращается в убеждение, в ценностную ориентацию и реализуется в деятельности, развивая способности личности. Личность индивидуализирует общественно необходимую деятельность, обогащая ее своими индивидуальными характеристиками, чем расширяет богатство всего общества. Результаты деятельности таких личностей часто включаются в сокровищницу культуры общества.

В условиях качественного преобразования общества важное значение приобретает осознанная целенаправленная самореализация личности. Целенаправленная самореализация предполагает, что личность должна сформировать в себе внутреннее стремление к овладению такими знаниями, которые выражают существенные связи природных и общественных условий ее существования. Эти знания личность получает в процессе образования. Самой важной составной частью такой самореализации личности выступает ее самообразование в соответствии с разработанной программой и ее реализацией. Данная сторона самореализации личности служит проявлением свободы личности и связана с выбором профессии, друзей, партнеров, самодеятельностью и т.п.

Такую самореализацию личности можно считать высшим проявлением человеческой субъективности, которая включает также контроль и овладения условиями, которые детерминируют существование индивидуальности личности. Таким образом, личность выражает то, что человеческая индивидуальность способна в рамках конкретных исторических условий максимально включаться в объективные процессы и сознательно создавать их совместно с другими индивидами. Это означает, что саморазвитие индивидуальности стимулирует развитие общества, содействует умножению его материального и духовного богатства. Индивидуальность определяется в этом процессе как высшее субъективное богатство общества, его высшая ценность.

В настоящее время общество требует от индивидов в некоторых видах их деятельности постоянного обновления профессиональных знаний, развития инициативы. Активные перемены в обществе создают общественную 
потребность в постоянном и непрерывном образовании, и, прежде всего, у людей с высшим и средним специальным образованием. Поэтому внутренней потребностью человека, неотъемлемой составной частью его жизни должно стать самообразование. Ценности, которые личность приобретает в процессе самообразования и самосовершенствования она может распространить в обществе, содействуя тем самым культурному обогащению сограждан.

На процесс самореализации личности воздействуют разные факторы общественной жизни: условия существования, свобода, система воспитания, образования, экономика, политика и др. Но основная роль в процессе самореализации личности принадлежит сфере труда, которая стимулирует активность личности, определяет целенаправленный характер ее деятельности и, в конечном счете, формирует потребность в самореализации. Именно в труде человек, прежде всего, осознает, что в его собственном развитии в равной мере заинтересован он сам и общество, в котором он живет и трудится. Сегодня в проблему самореализации привносятся новые моменты, обусловленные необходимостью преодоления сложившегося негативного отношения к труду, кризисных явлений в образовании и воспитании, выработки новой идеологической стратегии. Обновление общества выдвигает на первый план развитие индивидуальности человека с присущими ей профессионализмом, творческим потенциалом, инициативностью и ее целостную самореализацию. Целостная самореализация означает такую самореализацию личности, когда все сферы жизнедеятельности человека, все способы человеческого самоосуществления, в числе которых труд, общение, потребление, познание, досуг и другие, в принципе становятся равноценными, взаимообуславливают и взаимодополняют друг друга. Пока это историческая перспектива, тенденция. На пути ее реализации стоят еще многие нерешенные проблемы развития производства, научно-технического прогресса, труда с их конкретными противоречиями. Степень благоприятных для человека изменений, и, наоборот, неблагоприятных, прямо зависит от того, какое место занимает работник и его труд в системе общественных ценностей.

Выбирая тот или иной вид труда, человек руководствуется не только тяготением именно к данной профессии, а подчас, скорее всего желанием достичь определенного социального статуса. Следует осмыслить социальные корни столкновения общественной потребности и индивидуальных предпочтений при выборе профессий. Профессия имеет свою собственную объективную основу. Объективная основа профессии определяется не зависящей от человека совокупностью норм, обычаев, традиций, ценностей, методов деятельности, которые первоначально противостоят индивиду и вместе с тем выступают источником его опыта, знаний, оценок, которые он должен освоить и с необходимостью применять в своей профессиональной деятельности. Профессия есть процесс самореализации личности, осуществления ее воспроизводства и развития.

В настоящее время ярко выявляется противоречие, когда индивидуальные предпочтения при выборе профессии не соответствуют общественным потребностям. Дело в том, что лица, ориентированные на удовлетворенность работой, на творческий труд, представляют собой полную противоположность лицам, ориентированным только на материальное благосостояние. Для них характерны иная система ценностей, характер отношения, досуга, этические нормы. Это различие отчетливо фиксируется уже на уровне обыденного сознания, и задача заключается в том, чтобы реально и эффективно «подтягивать» уровень культуры у людей нетворческого труда. Поскольку в обозримом будущем практически недостижимо сделать труд в полной мере творческим для большинства населения, постольку необходимо научиться использовать все возможности, заложенные в обновляющейся социальной системе, чтобы повысить удовлетворенность людей своим трудом и сформировать у них творческое отношение к нему. Именно в труде раскрываются и природные способности человека, и привнесенные образованием и воспитанием. Труд, не дающий возможности разнообразного применения способностей, вряд ли может стать потребностью в современных условиях. А именно процесс становления и развития новых способностей и потребностей является одним из важнейших компонентов самореализации личности.

Способность человека к творчеству как способу самореализации социальной сущности является его неотъемлемым свойством. Но возможность и степень ее проявления зависит от социально-экономических условий. Особую значимость эта проблема приобретает в связи с переходом к рыночным отношениям. В этих отношениях с неизбежностью трансформируется содержание труда, его мотивы, культура труда, профессионализм и творчество.

Творчество представляет собой сложное социальное явление, в результате которого открываются более эффективные методы того или иного вида деятельности, создаются новые материальные и духовные ценности, существенно отличные от имеющихся, оригинальные предметы. Структура и механизм творческой деятельности включают такие элементы, как отражение человеком окружающей среды, накопление знаний, опыта, профессиональных умений, репродуктивную деятельность как базового элемента творчества, интуицию, воображение, построение мысленных моделей как эвристической основы творчества. 
Несомненно, что творческие виды труда представляют более полные возможности для самореализации индивидуальности. Специфика творческой деятельности заключается, прежде всего, в том, что в процессе творчества человек выступает творцом, реализует свою потребность в создании тех или иных предметов, явлений. Человек в процессе творчества создает и множит такие явления, в которых осуществлены фундаментальные свойства мира и его явлений: структурность, упорядоченность, гармоничность, красота. Творчество собственной жизни есть аспект любого творческого процесса человеческой деятельности.

Становление творческой индивидуальности человека осуществляется на практике посредством постоянного пополнения им своих знаний, умений, новаторских мотивов труда, оригинальных решений. Добиться более полного развития и использования творческих возможностей каждого человека - значит увеличить интеллектуальный потенциал всего общества. Это достигается также повышением качества подготовки молодежи к труду в жизни, без чего самореализация личности невозможна. Для становления творческих сил человека и его самореализации необходимым условием является свобода.
Потребность в свободе глубоко заложена в человеке, она имманентна любому виду его деятельности, связана с самой сутью природы человека. Человек постоянно предстает перед необходимостью свободно выбирать между различными альтернативами: выбор семьи, профессий, политических ориентаций, нравственных ценностей и т.п.

Именно в ситуации выбора с наибольшей полнотой раскрываются свойства человеческой индивидуальности, в том числе и потенциальные. Творческий момент в процессе выбора заключается в наличии вариантов решений, которые становятся результатом и условием самореализации и саморазвития личности. Свободный нравственный выбор - это вершина индивидуальных качеств, которых смог достичь человек в своем развитии, это уровень его индивидуальности. Жизнь человека есть постоянный процесс творчества, который всегда нуждается в свободе и вне которого он невозможен. В любом обществе уровень самореализации личности является показателем социального прогресса. Общество, заинтересованное в прогрессе, стремится к развитию индивидуальности каждого человека, расширению сферы его самореализации.

ЛИТЕРАТУРА

1. Буева Л.П. Человек как высшая ценность и главное богатство общества //Человек в системе наук. - М., 1989. - С. 497-498.

2. Фромм Э. Иметь или быть? - М., 1986. - С. 44.

3. Гегель Г.В.Ф. Эстетика. Т.1. - М., 1968. - С. 37.

4. Маркс К., Энгельс Ф. Т. 46, Ч.1. - С. 483-484.

(c) Апанасенко Ольга Николаевна (оараnasenko@bk.ru), Куряков Алексей Владимирович, Семенченко Ирина Витальевна. журнал «Современная наука: актуальные проблемы теории и практики» 